\title{
Potensi Bakteri Agens Hayati untuk Menekan infeksi Cucumber mosaic virus (CMV) pada Melon (Cucumis melo L.)
}

\author{
(The Potential of Bacterial Biological Agents to Suppress Cucumber mosaic virus (CMV) Infection \\ on Melon (Cucumis melo L.))
}

\author{
Iis Purnamawati ${ }^{1}$, Tri Asmira Damayanti ${ }^{1}$, dan Giyanto ${ }^{1 *}$ \\ ${ }^{1}$ Departemen Proteksi Tanaman, Fakultas Pertanian, Institut Pertanian Bogor \\ Jl. Kamper, Kampus IPB Dramaga, Bogor 16680 \\ Telepon/Faks: 0251-8629364/0251-8629362 \\ *Email korespondensi: giyanto@apps.ipb.ac.id
}

Diterima 11 Agustus 2019 / Disetujui 03 September 2019

\begin{abstract}
Cucumber mosaic virus (CMV) is an important pathogen of Cucurbitaceae, including melons. Virus management in the field is difficult to do. One of effort way to reduce viral infections is through improve plant health by using bacterial biological agents. This research was done to test the potential of bacterial isolates of Bacillus cereus (BC), Chromobacterium haemolyticum (CH), Ralstonia pickettii $(R P)$, and Pseudomonas flourescen $(P F)$ in suppressing CMV infections on melon plants. Bacteria effect testing through the performance of seedling was done by soaking the seeds in the bacterial suspension dan growing on test in laboratory. While efficacy of bacteria in suppressing CMV infection was conducted by soaking the seeds and spraying the plant with bacterial suspension in a greenhouse trial. Observations were measured on the disease and agronomic parameter, and peroxidase enzyme activity. The result showed that the treatment of BC bacteria showed the best germination performance among other bacteria treatment. Bacterial treatment did not affect the incubation period and the incidence of the disease, but it significantly decreases the severity of the disease and viral accumulation in compared with control. Peroxidase enzyme activity was higher after bacterial treatment and CMV inoculation in compared to treatment before inoculation. RP bacteria are the best bacteria in suppressing CMV infection through antiviral activity and induction of plant defense by increased peroxidase activity.
\end{abstract}

Keywords: biological control, cucurbitaceae, ISR, mosaic, peroxidase

\section{ABSTRAK}

Cucumber mosaic virus (CMV) merupakan patogen penting pada Cucurbitaceae, diantaranya melon. Pengelolaan virus di lapangan cukup sulit dilakukan. Salah satu upaya untuk menekan infeksi virus yaitu melalui penyehatan tanaman menggunakan bakteri agens hayati. Penelitian ini bertujuan menguji potensi isolat bakteri Bacillus cereus (BC), Chromobacterium haemolyticum (CH), Ralstonia pickettii (RP), dan Pseudomonas flourescens (PF) dalam menekan infeksi CMV pada tanaman melon. Pengujian pengaruh bakteri terhadap performa kecambah dilakukan melalui perlakuan perendaman benih dalam suspense bakteri di laboratorium. Efikasi bakteri dalam menekan infeksi CMV dilakukan dengan cara perendaman benih dan penyemprotan tanaman dengan suspense bakteri dalam percobaan di rumah kaca. Pengamatan dilakukan terhadap peubah penyakit dan agronomi, dan aktivitas enzim peroksidase. Hasil penelitian menunjukkan perlakuan bakteri BC menunjukkan performa kecambah terbaik di antara perlakuan bakteri lainnya. Perlakuan bakteri tidak berpengaruh terhadap masa inkubasi dan insidensi penyakit, namun secara nyata menurunkan keparahan penyakit dan akumulasi virus dibandingkan kontrol. Aktivitas enzim peroksidase lebih tinggi setelah perlakuan bakteri dan inokulasi CMV dibandingkan perlakuan sebelum inokulasi. Bakteri RP merupakan bakteri terbaik dalam menekan infeksi CMV melalui aktivitas antivirus dan induksi ketahanan dengan peningkatan aktivitas peroksidase.

Kata kunci: biokontrol, cucurbitaceae, ISR, mosaik, peroksidase

\section{PENDAHULUAN}

Melon merupakan salah satu buah-buahan yang banyak dikonsumsi oleh masyarakat Indonesia karena rasanya yang enak, aroma yang harum, dan mengandung nutrisi penting bagi tubuh manusia (Daryono et al. 2016). Produksi melon pada tahun 2015 hingga 2017 terus mengalami penurunan yaitu dari jumlah produksi 137887 menjadi 92434 ton (BPS 2019). Penurunan produksi melon dapat disebabkan oleh berbagai hal di antaranya penurunan 
luas lahan produksi, kualitas benih dan serangan hama juga patogen tanaman termasuk di dalamnya bakteri, cendawan, dan virus (Bezirganoglu 2018).

Salah satu virus penting pada melon adalah Cucumber mosaic virus (CMV) (Bezirganoglu 2018). Infeksi CMV pada melon di Spanyol dilaporkan telah menyebabkan kehilangan total produksi mencapai $60 \%$ (Alonso-Prados et al. 1997). Infeksi CMV pada melon di Indonesia di antaranya telah terjadi di wilayah Kabupaten Karanganyar dengan persentase kejadian penyakit $0.6 \%$ 64\% (Supyani et al. 2017). CMV merupakan salah satu dari tiga virus utama yang ditemukan menginfeksi mentimun di kabupaten Bogor, Subang, dan Karawang (Laili dan Damayanti 2019) dan pertanaman mentimun di Jawa (Listihani 2018).

CMV menyebabkan banyak kerugian hasil produksi tanaman karena kisaran inangnya yang luas serta keragaman karakter biologi dan molekulernya yang sangat banyak (Jacquemond 2012). Upaya pengelolaan virus tanaman secara umum yaitu seleksi benih, sanitasi lahan, penataan tanaman berkala, rotasi tanaman, dan penanaman tanaman pembatas (Reddy 2010).

Upaya lain pengelolaan CMV adalah menggunakan mikroba agens hayati. Beberapa isolat Streptomyces diketahui berpotensi menekan infeksi CMV sebesar 70.282.6\% (El Dougdoug 2012). Sementara itu, Pseudomonas putida Pf-20 mampu menekan keparahan penyakit mosaik oleh CMV pada mentimun sebesar $11.58 \%$ (Wahyuni et al. 2006). Bakteri agens hayati banyak dimanfaatkan dalam upaya pengelolaan virus patogen tanaman karena berpotensi mengontrol perkembangan penyakit tanaman, meningkatkan toleransi tanaman terhadap stres, memfasilitasi dan menginisiasi serapan unsur hara tanaman, serta meningkatkan hasil produksi (Hokeberg 2018).

Isolat bakteri GG6- Bacillus cereus (BC), NB9Chromobacterium haemolyticum (CH), TT47-Ralstonia picketii (RP), dan P12-Pseudomonas fluorescens (PF) dilaporkan efektif menekan infeksi bakteri dan cendawan patogen. BC dilaporkan mampu menghambat infeksi Dickeya dadantii pada daun anggrek sebesar 55.2\% (Khoiri et al. 2017). CH memiliki indeks kitinolitik (IK) yang tinggi dan dilaporkan mampu menghambat pertumbuhan Pyricularia oryzae serta Sclerotium rolfsii (Fitriani 2016). RP mampu menekan penyakit hawar pelepah padi yang disebabkan oleh Rizoctonia solani hingga 79.7\% (Rustam 2012). Mekanisme umum agens hayati dalam menekan patogen tanaman meliputi antibiosis, kompetisi, mikoparasitisme, enzim pendegradasi dinding sel, dan induksi ketahanan tanaman (Ahanger et al. 2014)

Potensi isolat bakteri tersebut di atas perlu diperluas kemampuannya dalam menekan patogen lainnya seperti virus. Oleh karena itu, penelitian ini bertujuan menguji potensi empat isolat bakteri untuk menekan infeksi CMV pada tanaman melon.

\section{BAHAN DAN METODE}

\section{Pengaruh Aplikasi Bakteri Agens Hayati terhadap Vigor Benih dan Pertumbuhan Melon}

Isolat bakteri yang diuji adalah milik laboratorium Bakteriologi Tumbuhan IPB, yaitu isolat $\mathrm{BC}, \mathrm{CH}, \mathrm{RP}$, dan PF. BC dan $\mathrm{CH}$ diperbanyak pada media NB (nutrient broth), sedangkan RP pada TSB (Tryptic soya broth), dan PF pada KB (King's B) cair (Schaad et al. 2001). Benih melon disterilisasi permukaan menggunakan larutan $\mathrm{NaOCl} 1 \%$ dan air steril (Schaad et al. 2001), kemudian direndam selama 5-6 jam dalam suspensi bakteri dengan kerapatan sel $10^{7}-10^{9} \mathrm{cfu} / \mathrm{mL}$. Kontrol hanya diberi perlakuan direndam dalam air steril.

Peubah yang diamati meliputi daya berkecambah, indeks vigor, tinggi kecambah, panjang akar, bobot basah, dan bobot kering saat hari kedelapan setelah semai. Bobot kering ditimbang ketika kecambah sudah dikeringkan selama 3x24 jam pada suhu $60{ }^{\circ} \mathrm{C}$ (Prawira 1999). Rancangan percobaan yang digunakan adalah rancangan acak lengkap (RAL) terdiri atas lima perlakuan $(\mathrm{K} ; \mathrm{BC}$; $\mathrm{CH}$; $\mathrm{RP}$; PF) dan empat ulangan, masing-masing ulangan terdiri dari sepuluh benih.

\section{Efikasi Bakteri Agens Hayati dalam Menekan infeksi Cucumber mosaic virus}

Penyiapan Inokulum CMV. Inokulum CMV diperoleh dari koleksi Laboratorium Virologi Tumbuhan asal melon dan diperbanyak melalui inokulasi mekanis pada tanaman dengan metode seperti yang dilakukan oleh Winarsih (2015).

Penyiapan media tanam dan benih melon. Media tanam terdiri atas tanah steril dan pupuk kandang (2:1) disiapkan pada polybag $(\mathrm{d}: 35 \mathrm{~cm})$. Benih melon yang ditanam adalah jenis rockmelon varietas Gracia F1. Setiap polybag ditanami 2-3 benih melon. Tanaman dengan pertumbuhan terbaik dipilih sebagai tanaman utama yang akan diamati.

Perlakuan. Benih melon disterilisasi permukaan dan diberi perlakuan bakteri seperti telah dijelaskan di atas, kemudian benih ditanam dalam polybag. Tiga hari sebelum penularan CMV, seluruh bagian tanaman uji disemprot dengan suspensi bakteri, Bakteri juga disemprotkan pada saat tanaman berumur empat minggu setelah tanam (MST). Tanaman kontrol tanpa bakteri, diinokulasi CMV (K). Tanaman kontrol sehat tidak diberi perlakuan apapun. Percobaan dilakukan di rumah kaca Cikabayan, Kampus IPB Dramaga, Bogor.

Peubah Pengamatan. Peubah yang diamati meliputi peubah penyakit yaitu masa inkubasi, insidensi penyakit, keparahan penyakit, tipe gejala, akumulasi virus pada empat minggu setelah inokulasi (MSI), dan aktivitas enzim peroksidase yang dianalisis sebanyak dua kali yaitu saat sebelum dan setelah inokulasi CMV.

Masa inkubasi dihitung sejak dilakukan inokulasi mekanis hingga waktu pertama kali munculnya gejala. Insidensi penyakit (IP) dihitung menggunakan rumus yang digunakan Townsend dan Heuberger (1943) sebagai berikut: IP $=$ [Jumlah tanaman sakit / Jumlah tanaman yang diamati $]$ $x 100 \%$

Penilaian keparahan gejala penyakit dilakukan mengikuti skor keparahan penyakit oleh Ntui et al. (2014), 
yaitu skor 0 -tidak bergejala-, skor $1-<25 \%$ dari luas daun mosaik ringan, skor $2-26 \%-50 \%$ dari luas daun -mosaik kuning dan malformasi, skor 3-50\%-75\% dari luas daun mosaik berat, dan skor $4->76 \%$ mosaik sangat berat. Hasil penilaian menggunakan skor tersebut selanjutnya diterapkan pada formula berikut untuk mendapatkan nilai keparahan penyakit secara keseluruhan pada setiap perlakuan:

$$
K P=\frac{\sum(n x v)}{N x V} \times 100 \%
$$

Keterangan: $\mathrm{KP}=$ Keparahan penyakit $(\%) ; \mathrm{n}=$ Jumlah tanaman bergejala skor ke-v; $\mathrm{v}=$ Skor gejala; $\mathrm{N}=$ Jumlah tanaman yang diamati; $\mathrm{V}=$ Skor tertinggi.

Pengamatan tipe gejala yang muncul dilakukan setelah perlakuan. Titer virus dianalisis melalui uji serologi ELISA (Enzyme Linked Immunosorbent Assay) sesuai dengan metode yang digunakan Winarsih (2015) dan produsen antiserum (DSMZ, Jerman). Setelah reaksi pewarnaan dengan PNP (p-nitrophenyl phosphate), hasil ELISA dikuantifikasi menggunakan ELISA reader pada panjang gelombang $405 \mathrm{~nm}$. Tingkat hambatan relatif titer virus dihitung menggunakan rumus sebagai berikut:

\section{$T H R=\{($ NAE kontrol - NAE perlakuan $) \div$ NAE kontrol $\} \times 100 \%$}

Analisis aktivitas enzim peroksidase dilakukan di Laboratorium Pusat Antar Universitas (PAU) IPB dengan metode yang digunakan oleh Kar dan Mishra (1976). Analisis dilakukan sebanyak dua kali yaitu saat sehari sebelum dan tiga hari setelah inokulasi CMV. Daun yang dianalisis merupakan sampel komposit dari seluruh tanaman pada setiap perlakuan.

Adapun peubah agronomi yang diamati meliputi tinggi tanaman, jumlah daun, lebar daun ketiga, waktu berbunga, jumlah tanaman berbunga, jumlah bunga, dan jumlah buah.

Percobaan dirancang dengan rancangan acak kelompok (RAK) yang terdiri dari lima perlakuan (empat perlakuan bakteri, satu kontrol tanpa bakteri) dan tiga ulangan. Tiap ulangan terdiri dari sepuluh tanaman. Data yang diperoleh dari seluruh kegiatan pengamatan ditabulasikan dalam perangkat lunak MS Excel 2016 dan dianalisis sidik ragam (analysis of variance-ANOVA) menggunakan program SPSS Statistics 25. Uji lanjut beda nyata menggunakan uji lanjut Tukey dengan taraf kepercayaan $95 \%$.

\section{HASIL DAN PEMBAHASAN}

\section{Vigor enih dan Pertumbuhan Kecambah Melon}

Berdasarkan hasil pengujian menunjukkan bahwa bakteri BC cenderung memiliki pengaruh yang baik terhadap vigor dan performa kecambah melon. Perlakuan bakteri BC nyata meningkatkan daya berkecambah jika dibandingkan dengan kontrol. Semantara itu, perlakuan bakteri RP dan PF berpengaruh sebaliknya, menurunkan daya berkecambah jika dibandingkan dengan kontrol. Perlakuan bakteri $\mathrm{CH}$ tidak berpengaruh terhadap daya berkecambah jika dibandingkan dengan kontrol (Tabel 1). Bacillus merupakan salah satu bakteri yang memproduksi hormon auksin (Ahmad et al. 2006). Pengaruh auksin terhadap pertumbuhan awal tanaman adalah merangsang perkecambahan biji dan umbi (Spaepen et al. 2006).

Indeks vigor benih melon pada perlakuan bakteri RP dan PF nyata lebih rendah dibandingkan dengan control dan tidak berbeda nyata dengan kontrol pada perlakuan BC dan $\mathrm{CH}$. Pengaruh perlakuan keempat bakteri tidak berbeda nyata dengan kontrol pada peubah pengamatan tinggi kecambah, panjang akar, dan bobot basah kecambah. Sementara itu, bobot kering kecambah nyata lebih rendah dari kontrol pada perlakuan bakteri BC. Sedangkan pada perlakuan $\mathrm{CH}$, RP, dan $\mathrm{PF}$, bobot kering tidak berbeda nyata dengan kontrol (Tabel 1).

Berdasarkan hasil di atas, perlakuan BC lebih baik dalam meningkatkan vigor benih melon dibandingkan dengan ketiga bakteri lainnya yang diujikan. Aplikasi $B$. cereus UW85 dilaporkan secara signifikan meningkatkan hasil dari kedelai kultivar resisten atau toleran di lapangan (Osburn et al. 1995). B. cereus juga dilaporkan berpotensi dalam memicu pertumbuhan dan inducing systemic resistance (ISR) tanaman cabai (Capsicum annuum L. var. TM 999) terhadap infeksi Tobacco mosaic tobamovirus (TMV) (Damayanti et al. 2007), dan TMV serta Chili veinal mottle virus (ChiVMV) (Damayanti dan Katerina 2008). Selain itu, banyak spesies Bacillus lainnya diketahui berperan sebagai endofit atau agens hayati bagi patogen tanaman (Schaad et al. 2001). Aktivitas antagonis Bacillus terhadap patogen tanaman melalui produksi siderofor, sekresi enzim, produksi antibiotik, dan ISR (Aboutorabi 2018).

\section{Pengaruh bakteri agens hayati terhadap infeksi CMV pada melon}

Keempat perlakuan bakteri agens hayati tidak berpengaruh nyata terhadap masa inkubasi dan insidensi penyakit dibandingkan dengan kontrol. Namun, perlakuan bakteri $\mathrm{BC}, \mathrm{CH}, \mathrm{RP}$, dan $\mathrm{PF}$ nyata dapat menurunkan persentase keparahan penyakit dibandingkan dengan kontrol (Tabel 2). P. flourescens dilaporkan mampu menginduksi ketahanan sistemik tanaman melon terhadap CMV dan menghambat multiplikasi CMV hingga $86.55 \%$ (Al-Ani dan Adhab 2012).

Nilai absorbansi ELISA (NAE) hasil ELISA pada perlakuan $\mathrm{CH}$, RP, dan $\mathrm{PF}$ nyata lebih rendah dibandingkan dengan kontrol. Sedangkan nilai NAE pada perlakuan BC tidak berbeda nyata dengan kontrol. Hasil ELISA pada semua perlakuan bakteri menunjukkan positif pada semua perlakuan (Tabel 2). Kemampuan bakteri yang diuji menunjukkan mampu menekan titer virus berkisar 19.19$31.95 \%$. Namun, baik tanaman kontrol maupun perlakuan bakteri menunjukkan NAE relatif rendah dan tidak berkorelasi dengan keparahan penyakit yang cukup tinggi. 
Tabel 1. Pengaruh aplikasi bakteri agens hayati terhadap perkecambahan benih melon

\begin{tabular}{|c|c|c|c|c|c|c|}
\hline Perlakuan $^{a}$ & $\begin{array}{c}\text { Daya } \\
\text { berkecambah }^{\mathrm{b}} \\
(\%)\end{array}$ & $\begin{array}{c}\text { Indeks } \\
\text { vigor }^{\mathrm{b}}(\%)\end{array}$ & $\begin{array}{l}\text { Tinggi } \\
\text { kecambah }^{\mathrm{b}} \\
(\mathrm{cm})\end{array}$ & $\begin{array}{c}\text { Panjang } \\
\text { akar }^{\mathrm{b}}(\mathrm{cm})\end{array}$ & $\begin{array}{c}\text { Bobot } \\
\text { basah }^{\text {b }}(\text { gram })\end{array}$ & $\begin{array}{c}\text { Bobot } \\
\text { kering }^{\text {b }(g r a m)}\end{array}$ \\
\hline K & $92.50 \pm 2.04 \mathrm{~b}$ & $95.00 \pm 4.08 \mathrm{ab}$ & $7.00 \pm 0.222 \mathrm{ab}$ & $4.80 \pm 0.184 a b$ & $1.293 \pm 0.313 \mathrm{ab}$ & $0.030 \pm 0.001 \mathrm{ab}$ \\
\hline $\mathrm{BC}$ & $98.33 \pm 2.36 \mathrm{a}$ & $96.67 \pm 4.71 \mathrm{a}$ & $7.46 \pm 0.155 \mathrm{a}$ & $5.16 \pm 0.340 \mathrm{a}$ & $1.650 \pm 0.135 \mathrm{a}$ & $0.021 \pm 0.007 \mathrm{c}$ \\
\hline $\mathrm{CH}$ & $90.00 \pm 0.00 \mathrm{~b}$ & $90.00 \pm 0.00 \mathrm{~b}$ & $6.11 \pm 0.142 b$ & $4.71 \pm 0.292 \mathrm{ab}$ & $0.983 \pm 0.180 \mathrm{~b}$ & $0.030 \pm 0.001 \mathrm{ab}$ \\
\hline $\mathrm{RP}$ & $82.50 \pm 2.04 c$ & $80.00 \pm 0.00 c$ & $6.31 \pm 0.766 b$ & $4.87 \pm 0.214 \mathrm{ab}$ & $0.963 \pm 0.119 b$ & $0.022 \pm 0.003 b c$ \\
\hline PF & $85.00 \pm 0.00 \mathrm{c}$ & $80.00 \pm 0.00 c$ & $6.30 \pm 0.416 b$ & $4.26 \pm 0.406 b$ & $1.257 \pm 0.189 \mathrm{ab}$ & $0.036 \pm 0.003 a$ \\
\hline
\end{tabular}

a) $\mathrm{K}=$ Kontrol (tanpa bakteri), $\mathrm{BC}=B$. cereus, $\mathrm{CH}=$ C.haemolyticum, $\mathrm{RP}=R$. pickettii, $\mathrm{PF}=P$. flourescens;

${ }^{b}$ Angka pada lajur yang sama yang diikuti dengan huruf yang sama tidak berbeda nyata berdasarkan uji Tukey pada taraf nyata $5 \%$.

Tabel 2. Pengaruh aplikasi bakteri agens hayati terhadap penyakit mosaik oleh CMV pada tanaman melon

\begin{tabular}{lccccc}
\hline Perlakuan $^{\mathrm{a}}$ & $\begin{array}{c}\text { Masa inkubasi } \\
(\text { hari) }\end{array}$ & $\begin{array}{c}\text { Insidensi } \\
\text { penyakit }(\%)\end{array}$ & $\begin{array}{c}\text { Keparahan }_{\text {penyakit }^{\mathrm{b}}(\%)} \\
\text { NAE }\end{array}$ & THR $^{\mathrm{b}}(\%)^{\mathrm{c}}$ \\
\hline $\mathrm{K}$ & $6.9 \pm 0.10 \mathrm{a}$ & 100 & $60.0 \pm 2.50 \mathrm{a}$ & $0.482 \pm 0.068 \mathrm{a}$ & 19.19 \\
$\mathrm{BC}$ & $9.9 \pm 3.45 \mathrm{a}$ & 100 & $47.4 \pm 0.15 \mathrm{bc}$ & $0.390 \pm 0.024 \mathrm{ab}$ & 31.95 \\
$\mathrm{CH}$ & $7.2 \pm 0.10 \mathrm{a}$ & 100 & $51.4 \pm 1.40 \mathrm{~b}$ & $0.328 \pm 0.025 \mathrm{~b}$ & 30.60 \\
$\mathrm{RP}$ & $7.6 \pm 1.00 \mathrm{a}$ & 100 & $41.3 \pm 1.25 \mathrm{~d}$ & $0.335 \pm 0.001 \mathrm{~b}$ & 28.48 \\
$\mathrm{PF}$ & $7.4 \pm 0.35 \mathrm{a}$ & 100 & $42.5 \pm 2.50 \mathrm{~cd}$ & $0.345 \pm 0.005 \mathrm{~b}$ & \\
\hline
\end{tabular}

a) $\mathrm{K}=\mathrm{Kontrol}$ (tanpa bakteri), $\mathrm{BC}=B$. cereus, $\mathrm{CH}=$ C.haemolyticum, $\mathrm{RP}=R$. pickettii, $\mathrm{PF}=P$. flourescens;

b) Angka pada lajur yang sama yang diikuti dengan huruf yang sama tidak berbeda nyata berdasarkan uji Tukey pada taraf nyata $5 \%$. Uji dinyatakan positif jika NAE sampel $\geq 0.310 .{ }^{\mathrm{c}} \mathrm{THR}$. Tingkat hambatan relative

Tabel 3. Pengaruh aplikasi bakteri agens hayati terhadap pertumbuhan dan perkembangan tanaman melon

\begin{tabular}{|c|c|c|c|c|c|c|}
\hline Perlakuan $^{a}$ & $\begin{array}{c}\text { Tinggi } \\
\text { tanaman }^{b} \\
(\mathrm{~cm})\end{array}$ & $\begin{array}{l}\text { Jumlah } \\
\text { daun }^{\text {b }} \\
\text { (helai) }\end{array}$ & $\begin{array}{l}\text { Lebar } \\
\text { daun }^{\text {b }} \\
(\mathrm{cm})\end{array}$ & $\begin{array}{c}\text { Waktu } \\
\text { berbunga } \\
\text { (hari) }\end{array}$ & $\begin{array}{l}\sum \text { tanaman } \\
\text { berbunga }^{\mathrm{b}} \\
\text { (tanaman) }\end{array}$ & $\sum$ bunga $^{\mathrm{b}}$ (tangkai) \\
\hline $\mathrm{K}$ & $116.84 \pm 5.27 \mathrm{ab}$ & $16.30 \pm 0.80 \mathrm{~b}$ & $10.32 \pm 0.46 a$ & $34.42 \pm 0.09 \mathrm{ab}$ & $10.00 \pm 0.00 \mathrm{a}$ & $14.95 \pm 1.05 \mathrm{ab}$ \\
\hline $\mathrm{BC}$ & $126.15 \pm 2.54 \mathrm{a}$ & $19.61 \pm 0.51 \mathrm{a}$ & $9.20 \pm 0.78 \mathrm{a}$ & $34.68 \pm 0.99 \mathrm{ab}$ & $9.50 \pm 0.50 \mathrm{a}$ & $18.91 \pm 0.69 \mathrm{ab}$ \\
\hline $\mathrm{CH}$ & $100.79 \pm 2.46 \mathrm{c}$ & $19.32 \pm 1.12 \mathrm{a}$ & $9.53 \pm 0.48 \mathrm{a}$ & $35.16 \pm 0.05 \mathrm{a}$ & $10.00 \pm 0.00 \mathrm{a}$ & $20.15 \pm 2.85 a$ \\
\hline $\mathrm{RP}$ & $116.02 \pm 8.26 a b c$ & $17.75 \pm 1.15 \mathrm{ab}$ & $9.36 \pm 0.20 \mathrm{a}$ & $32.97 \pm 0.47 b$ & $9.50 \pm 0.50 \mathrm{a}$ & $17.45 \pm 4.05 \mathrm{ab}$ \\
\hline $\mathrm{PF}$ & $108.06 \pm 7.06 \mathrm{bc}$ & $19.65 \pm 1.15 \mathrm{a}$ & $9.45 \pm 0.28 \mathrm{a}$ & $33.50 \pm 1.00 \mathrm{ab}$ & $10.00 \pm 0.00 \mathrm{a}$ & $14.50 \pm 0.40 \mathrm{~b}$ \\
\hline
\end{tabular}

${ }^{\mathrm{a}} \mathrm{K}=$ Kontrol (tanpa bakteri); $\mathrm{BC}=$ B. cereus $; \mathrm{CH}=$ C.haemolyticum $; \mathrm{RP}=$ R. pickettii $; \mathrm{PF}=$ P. flourescens;

${ }^{\mathrm{b}}$ Angka pada lajur yang sama yang diikuti dengan huruf yang sama tidak berbeda nyata berdasarkan uji Tukey pada taraf nyata $5 \%$.

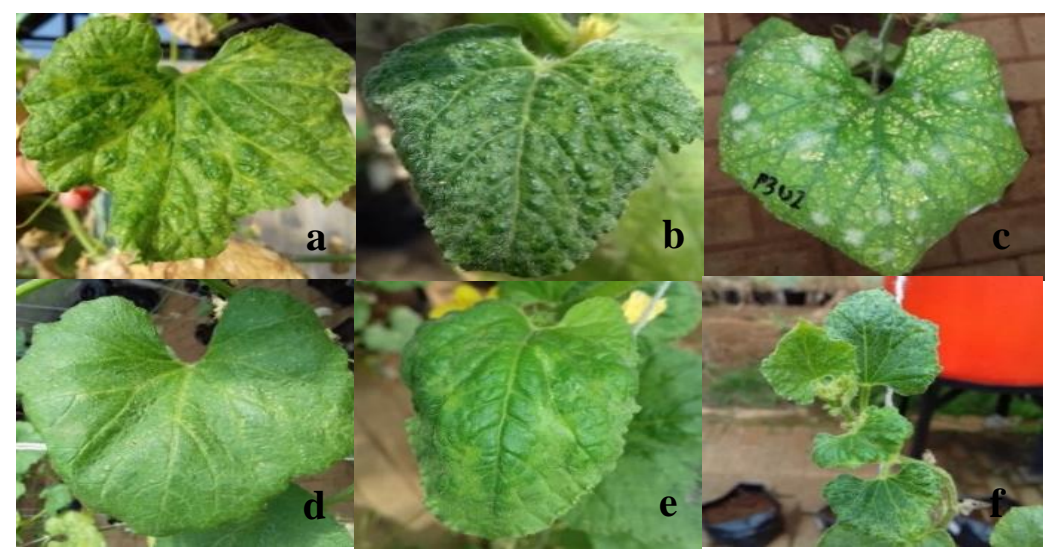

Gambar 1. Gejala infeksi CMV pada tanaman melon. (a) Mosaik, (b) Rugos, (c) Penebalan tulang daun, (d) Pemucatan tulang daun, (e) Malformasi daun, (f) Kerdil. 

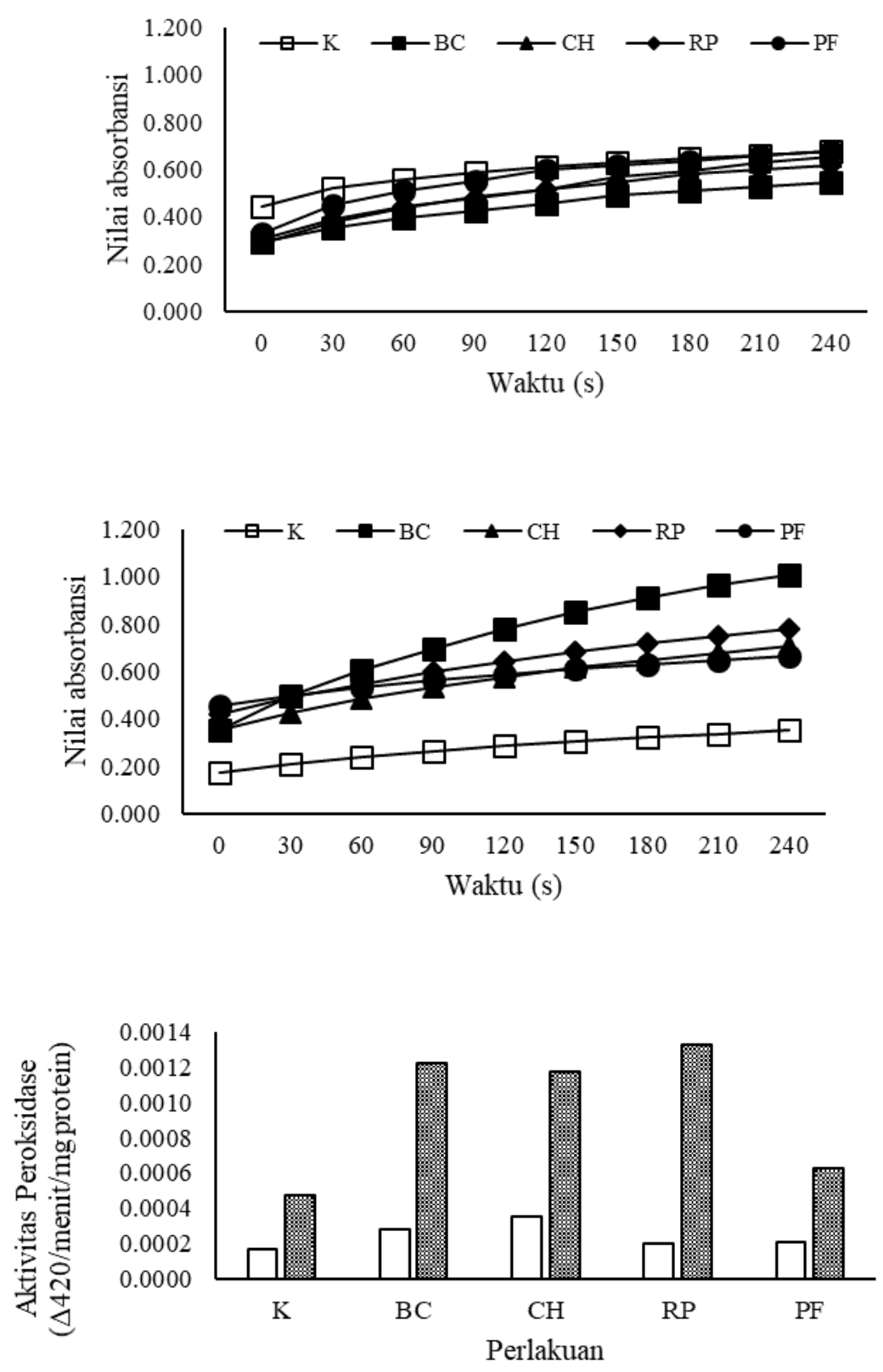

口Sebelum inokulasi CMV @ Setelah inokulasi CMV

Gambar 2. Aktivitas enzim peroksidase tanaman melon sebelum (a), setelah (b) inokulasi CMV dan total aktivitas enzim peroksidase (c).

Ada kemungkinan terjadi infeksi ganda di rumah kaca yang ditularkan kutu daun dari sekitar rumah kaca. Selama penelitian, populasi kutu daun cukup tinggi. Interaksi dua virus dapat menyebabkan gejala lebih parah dibandingkan infeksi tunggal virus. Hal ini telah dilaporkan terjadi antara African cassava mosaic virus (ACMV) dengan East African cassava mosaic virus (EACMV) pada tanaman singkong di Ghana (Oteng-frimpong et al. 2012; Mascia et al. 2010). Interaksi dua virus juga dapat menyebabkan konsentrasi salah satu virus menurun. Infeksi CMV dengan potyvirus menyebabkan infeksi yang sinergi terhadap gejala dan konsentrasi virus. Namun, jika infeksi potyvirus dengan CMV yang mengandung satelit RNA, akan menyebabkan konsentrasi CMV menurun (Wang et al. 2002).

Hasil penelitian ini selaras dengan laporan Erlika (2016) bahwa CMV strain Soybean yang diberi perlakuan filtrat bakteri menunjukkan kemampuan menekan akumulasi CMV-S pada kedelai. Filtrat bakteri dilaporkan berpengaruh terhadap penyebaran dan replikasi virus (Thapa et al. 2009).

Gejala infeksi CMV pada tanaman melon yang diamati bervariasi. Gejala mosaik merupakan gejala yang dominan dan muncul pada semua perlakuan. Gejala lain 
yang ditemukan yaitu rugos, penebalan tulang daun, pemucatan tulang daun, malformasi daun, dan kerdil (Gambar 1). Perubahan bentuk daun dan pengerdilan ukuran tanaman merupakan gejala lanjutan dari infeksi CMV (Zitter dan Murphy 2009).

\section{Aktivitas enzim peroksidase tanaman}

Aktivitas peroksidase lebih tinggi setelah inokulasi CMV. Peningkatan aktivitas enzim peroksidase juga lebih tinggi pada tanaman yang diberi perlakuan bakteri, dibandingkan dengan kontrol (Gambar 2a dan 2b). Peningkatan aktivitas PO tertinggi ditunjukkan oleh perlakuan RP, sedangkan paling rendah pada perlakuan kontrol (Gambar 2c). Menurut Prasannath (2017) aktivitas enzim peroksidase diinduksi di dalam jaringan tanaman oleh adanya infeksi patogen. Aktivitas peroksidase pada tanaman bunga matahari genotipe resisten lebih tinggi dibandingkan dengan tanaman bunga matahari genotipe rentan. Hal tersebut memberikan bukti yang kuat bahwa peroksidase merupakan enzim penting dalam sistem pertahanan tanaman bunga matahari terhadap infeksi Alternaria helianthin (Anjana et al. 2008). Beberapa proses yang terlibat dalam induksi ketahanan tanaman yang dipicu oleh peroksidase adalah reaksi hipersensitif, lignifikasi, sintesis fenol, glikoprotein, suberisasi, dan produksi fitoaleksin (Wojtaszek 1997).

\section{Pengaruh perlakuan bakteri agens hayati terhadap pertumbuhan dan perkembangan tanaman melon}

Perlakuan bakteri pada tanaman yang diinokulasi CMV tidak nyata berpengaruh terhadap tinggi tanaman, lebar daun, waktu berbunga, jumlah bunga dan buah dibandingkan kontrol. Namun, perlakuan bakteri agens hayati nyata meningkatkan jumlah daun dibandingkan kontrol kecuali perlakuan RP (Tabel 3).

Pseudomonas merupakan bakteri selain Bacillus yang berpotensi dalam memicu pertumbuhan tanaman diantaranya karena mampu memproduksi hormon auksin (Ahmad et al. 2005). Pengaruh auksin terhadap pertumbuhan vegetatif tanaman yaitu mempengaruhi pembelahan sel tanaman, meningkatkan laju perkembangan xilem dan akar, memediasi respon tanamn terhadap rangsangan, dan mempengaruhi fotosintesis (Spaepen et al. 2006).

\section{KESIMPULAN}

Perlakuan bakteri BC, CH, RP, dan PF nyata mampu menurunkan keparahan penyakit dan akumulasi virus dibandingkan dengan kontrol. Keempat isolat berpotensi dalam menekan infeksi TMV dengan menginduksi ketahanan tanaman melon melalui peningkatan aktivitas peroksidase. Perlu dilakukan pengujian lebih lanjut aplikasi bakteri berulang dan kombinasi bakteri agens hayati ini untuk meningkatkan efektivitasnya dalam menekan infeksi CMV.

\section{DAFTAR PUSTAKA}

Aboutorabi, M. 2018. A review on the biological control of plant diseases using various microorganisms. J Res Med Sci. 6(4):30-35.

Ahanger, R.A., H.A. Bhatand dan N.A. Dar. 2014. Biocontrol agents and their mechanism in plant disease management. Sci Acta Xaveriana. 5(1):47-58.

Ahmad, F., I. Ahmad dan M.S. Khan. 2008. Screening of free-living rhizospheric bacteria for their multiple plant growth promoting activities. Microb Res. 163:173-181.

Al-Ani, R.A. dan M.A. Adhab. 2012. Protection of melon plants against Cucumber mosaic virus infection using Pseudomonas flourescens biofertilizer. Afr $J$ Biotechnol. 11(100):16579-16585.

Alonso-Prados, J.L., A. Fraile, F. dan Garcia-Arenal. 1997. Impact of Cucumber mosaic virus and Watermelon mosaic virus 2 infection on melon production in Central Spain. Plant Pathol J. 79 (2):131-134.

Anjana, G., K.R. Kini, H.S. Shetty dan H.S. Prakash. 2008. Changes in peroxidase activity in sunflower during infection by necrotrophic pathogen Alternaria helianthi. Arc Phytopathol Plant Protect. 41(8):586596.

Bezirganoglu, I. 2018. Botany of Cucumis melo. Hort Int J. 2(3).

[BPS] Badan Pusat Statistik. 2019. Produksi Tanaman Buah-Buahan: Melon. https://www.bps.go.id/site/resultTab [26 Maret 2019].

Damayanti, T.A., H. Pardede dan N.R. Mubarik. Utilization of root-coloning bacteria to protect hot-pepper against Tobacco Mosaic Tobamovirus. Hayati. 14(3):105-109.

Daryono, B.S., S.D. Maryanto, S. Nissa dan G.R. Aristya. 2016. Analisis kandungan vitamin pada melon (Cucumis melo L.) kultivar melodi gama 1 dan melon komersial. Biogenesis. 4(1):1-9.

Damayanti, T.A. dan T. Katerina. 2008. Protection of hot pepper against multiple infection of viruses by utilizing root colonizing bacteria. J Int Soc Southeast Asian Agric Sci. 14(1): 92-100.

Dhillon, M.K., R. Singh, J.S. Naresh dan H.C. Sharma. 2005. The melon fruit fly, Bactrocera cucurbitae: A review of its biology and management. J of Insect Sci. 5(40).

El-Dougdoug, K.A., M.F. Ghaly, M.A. Taha. 2012. Biological control of Cucumber mosaic virus by Certain Local Sreptomyces Isolates: Inhibitory 
Effects of Selected Five Egyptian Isolates. Intl $J$ Virol. 8(2):151-164.

Erlika, L. 2016. Pemanfaatan filtrat bakteri endofit dan plant growth promoting rhizobacteria untuk menekan infeksi Cucumber mosaic virus strain Soybean (CMV-S) pada tanaman kedelai. Skripsi. Bogor (ID): Departemen Proteksi Tanaman. Institut Pertanian Bogor.

Fitriani, D. 2016. Isolasi, seleksi, dan identifikasi bakteri kitinolitik pada cairan tanaman kantong semar (Nepenthes spp.) sebagai agens biokontrol. Skripsi. Bogor (ID): Departemen Proteksi Tanaman. Institut Pertanian Bogor.

Hokeberg, M. 2018. Bacteria in biological control. Uppsala (Sweden): Centre for Biological Control, CBC.

Jacquemond, M. 2012. Cucumber mosaic virus. Adv Virus Res. 84: 439-504.

Kar, M. dan D. Mishra. 1976. Catalase, peroxidase, and polyphenoloxidase activities during rice leaf senescence. J Plant Physiol. 57(2):315-9.

Khoiri, S. Giyanto dan T.A. Damayanti. 2017. Identification of quorum quenching bacteria and its biocontrol potential against soft rot disease bacteria, Dickeya dadantii. AGRIVITA. 39(1):45-55.

Laili, N.U. dan T.A. Damayanti. 2019. Deteksi virus pada tanaman mentimun di Jawa Barat. Agrovigor. 12(1):8-15.

Listihani. 2018. Distribusi dan identifikasi virus utama pada mentimun di Jawa. Tesis. Sekolah Pascasarjana. Institut Pertanian Bogor. Bogor.

Mascia, T., F. Chillo, V. Fanelli, M.M. Finetti-Sialer, A. De Stradis, P. Palukaitis dan D. Gallitelli. 2010. Characterization of the interactions between Cucumber mosaic virus and Potato virus $\mathrm{Y}$ in mixed infection in tomato. $J$ Mol Plant-Microbe Int. 23(11):1514-1524.

Ntui, V.O., K. Kong, P. Azadi, R.S. Khan, D.P. Chin, T. Igawa, M. Mii dan I. Nakamura. 2014. RNAimediated resistance to Cucumber mosaic virus (CMV) in genetically engineered tomato. Am J Plant Sci. 5:554-572.

Osburn, R.M., J.L. Milner, E.S. Oplinger, R.S. Smith dan J. Handelsman. 1995. Effect of Bacillus cereus UW85 on the yield of soybean at two field sites in Wisconsin. Plant Dis. 79:551-556.

Oteng-Frimpong, R., Y. Levy, S.K. Torkpo, E.Y. Danquah, S.K. Offei dan Y. Gafni. 2012. Complete genome sequencing of two causative viruses of cassava mosaic disease in Ghana. Acta Virol. 56(4):305-314.

Prasannath, K. 2017. Plant defense-related enzymes against pathogens: A Review. Department of Agricultural Biology. Faculty of Agriculture, Eastern University Sri Lanka. Chenkalady.

Prawira, J. 1999. Studi Pematahan Dormansi dan Perlakuan Air Kelapa untuk Meningkatkan Perkecambahan Benih Gmelina arborea. Skripsi. Jurusan Budidaya Pertanian, Fakultas Pertanian. Institut Pertanian Bogor. Bogor.

Reddy, P.P. 2010. Bacterial Viral Disease and Their Management in Horticultural Crops. Scientific Publishers, Bangalore, IN.

Rustam. 2012. Potensi bakteri penghasil senyawa bioaktif anticendawan untuk pengendalian penyakit hawar pelepah padi. Disertasi. Sekolah Pascasarjana. Institut Pertanian Bogor. Bogor.

Schaad, N.W., J.B. Jones dan W. Chun. 2001. Laboratory Guide for Identification of Plant Pathogenic Bacteria Third Edition. The American Phytopathology Society. Minnesota.

Spaepen, S., J. Vanderleyden dan R. Remans. 2006. Indole-3 acetic acid in microbial and microorganism-plant signaling. FEMS Microbiol Rev. 31: 425-448.

Supyani, S.A. Chandra, F. Rochman, D.N. Septariani dan S. Widadi. 2017. Occurrence and distribution of Cucumber mosaic virus in cucurbits in Karanganyar, Central Java, Indonesia. Afr J Agric Res. 12(18): 1593-1601.

Thapa, S.P., H.J. Lee, D.H. Park, S.K. Kim, J.M. Cho, S. Cho, J.H. Hur dan C.K. Lim. 2009. Antiviral effects of the culture filtrate from Serratia marcescens Gsm01 against Cucumber mosaic virus (CMV). Plant Pathol J. 25(4):369-375.

Townsend, G.R. dan J.W. Heuberger. 1943. Methods for estimating losses caused by diseases in fungicides experiments. Plant Dis Rep. 27: 340-343.

Wahyuni, W.S., H.S. Addy, B. Arman dan T.C. Setyowati. 2006. Sinergisme Lumbricus rubellus dengan Pseudomonas putida Pf-20 dalam Menginduksi Ketahanan Mentimun terhadap Cucumber Mosaic Virus. Hayati. 13(3):95-100.

Wang, Y., V. Gaba, J. Yang, P. Palukaitis dan A. Gal-On. 2002. Characterization of synergy between Cucumber mosaic virus and potyvirus in cucurbits host. Phytopathology. 92(1):51-58. 
Winarsih. 2015. Respons ketahanan sepuluh kultivar mentimun (Cucumis sativus L.) terhadap infeksi Cucumber mosaic virus. Bogor (ID): Departemen Proteksi Tanaman. Institut Pertanian Bogor.
Wojtaszek, P. 1997. The oxidative burst plants early response against infection. Biochem J. 322: 681-692.

Zitter, T.A. dan J.F. Murphy. 2009. Cucumber mosaic virus. The Plant Health Instructor. DOI: 10.1094. 